Aletria, Belo Horizonte, v. 30, n. 2, p. 103-124, 2020

(c) (1)

\title{
Configurações do espaço, corpo e paisagem em Guimarães Rosa
}

\section{Space, Body and Landscape Settings in Guimarães Rosa}

\author{
Edinilia Nascimento Cruz \\ Instituto Federal do Norte de Minas Gerais (IFNMG), Montes Claros, Minas Gerais \\ / Brasil \\ ediniliabr@yahoo.com.br \\ http://orcid.org/0000-0002-8805-7997
}

\begin{abstract}
Resumo: O núcleo desta reflexão é a análise da relação entre corpo e paisagem, tema ainda insuficientemente explorado na obra de Guimarães Rosa, e as formas como a paisagem se transforma em componentes literários em Corpo de baile (1956), com base na noção de paisagem literária de Michel Collot e na fenomenologia da percepção de Merleau-Ponty. $\mathrm{O}$ artigo problematiza o espaço e os corpos nas narrativas rosianas tomando como base as construções paisagísticas, que atuam como forças criadoras da perspectiva experiencial das personagens. Com efeito, o espaço e a paisagem no contexto dessa leitura são percebidos pelas personagens através dos órgãos sensoriais, que têm como mediador o corpo.
\end{abstract}

Palavras-chave: Corpo de baile; paisagem; espaço; Guimarães Rosa.

Abstract: The core of this reflection is the analysis of the relationship between body and landscape, which is still a theme insufficiently explored in Guimarães Rosa's work, and the ways as the landscape transforms in literary components in Corpo de Baile (1956), based on Michel Collot's notion of literary landscape and Merleau-Ponty's phenomenology of perception. The article problematizes the space and the bodies in Rosa's narratives based on the landscape constructions, which act as creative forces of the experiential perspective of the characters. As a result, the space and the landscape in the context of this reading are perceived by the characters through the sensory organs, which have as mediator the body.

Keywords: Corpo de Baile; landscape; space; Guimarães Rosa. 
A expressão "corpo de baile", que dá título ao livro, significa, de acordo com o dicionário Houaiss, "conjunto permanente de bailarinos que executam danças clássicas e/ou folclóricas" (HOUAISS, 2001, p. 843). Desse modo, o corpo contempla "a substância, a matéria, tudo o que ocupa lugar; tudo o que tem existência física e extensão no espaço" (HOUAISS, 2001, p. 843). Das várias dimensões do significado de corpo no livro, seja ele na acepção de corpo social, corpo cultural, corpo histórico e corpo humano, destaca-se o corpo como mediador da interioridade humana com o mundo. Pode-se dizer que essa relação sugerida pela articulação entre o corpo do título, o corpo do livro e o corpo das personagens assume várias formas e amplia o quadro referencial de sua significação nas narrativas. $\mathrm{O}$ corpo é assim compreendido como conjunto de relações.

Michel Collot defende que há uma intrínseca relação entre corpo e mundo. Segundo o crítico, "essa solidariedade entre corpo perceptor e o mundo percebido é ilustrada pela experiência da paisagem, cuja aparência está ligada a um ponto de vista encarnado" (COLLOT, 2013, p. 38). O corpo é o veículo para a interação perceptiva. Dessa forma, a paisagem é vista como uma realidade experimentada pelas personagens.

A paisagem pode ser entendida a partir das implicações cognitivas que consistem na relação perceptiva da personagem no espaço. Maurice Merleau-Ponty, em Fenomenologia da percepção, aborda a relação "ser no mundo" assinalando a importância da experiência vivida e da experiência perceptiva. De acordo com o teórico, o corpo atua como mediador na aproximação do homem com o mundo por meio dos sentidos. Essa abordagem fenomenológica é fundamental na compreensão da percepção espacial que toma como ênfase os sentidos do corpo.

Para Merleau-Ponty, a subjetividade está intrinsecamente relacionada com a forma com que o sujeito atua no mundo. Assim, a subjetividade é corporificada, o corpo é fundamento para a consciência, de modo que este é visto como parte de nossa experiência e de nosso estar físico no mundo. Ao tratar da espacialidade e da percepção, no campo das interações, Merleau-Ponty destaca que "nosso corpo não está primeiramente no espaço: ele é no espaço" (MERLEAU-PONTY, 2011, p. 205, grifo nosso). Há um entrelaçamento entre o espaço vivido existencial e o espaço natural da percepção, que faz com que o homem se organize no universo por meio das representações. 
Em Corpo de baile, a experiência perceptiva das personagens faz parte da própria referência espacial do sertão-gerais. O deslocamento físico e a aprendizagem interior dos protagonistas estão associados à condição de estar no mundo. A partir da vivência e da relação de pertencimento ao lugar, as personagens desenvolvem sentimentos de afetividade ou de rejeição, que são motivados pelas experiências sociais e intersubjetivas, e interferem no modo como percebem e estruturam seus mundos. Manuelzão, em "Uma estória de amor", vive essa experiência na Samarra. A partir da reorganização constante do pensamento, que vai se constituindo no ambiente da festa, busca um equilíbrio, entre o ser e o ter, por mecanismos inter-relacionados:

Triste que aquilo tudo não pertencesse - pois o dono por detrás era Federico Freyre. A ver, ele, Manuelzão, era somenos. Possuía umas dez-e-dez vacas, uns animais de montar, uns arreios. Possuía nada. Assentasse de sair dali, com o seu, e descia as serras da miséria. Quisesse guardar as reses em que pasto que pôr? E, quisesse adquirir, longe, um punhadinho de alqueires, então tinha de vender primeiro as vacas para o dinheiro de comprar. Possuía? Os cotovelos! Era mesmo quase igual com o velho Camilo... Agora, sobressentia aquelas angústias de ar, a sopitação, até uma dor-de-cabeça; nas pernas, nos braços, uma dormência. A aflição dos pensamentos. Parece que eu vivo, vivo, e estou inocente. Faço e faço, mas não tem outro jeito: não vivo encalcado, parece que estou num erro... Ou que tudo que eu faço é copiado ou fingimento, eu tenho vergonha, depois... Ah, ele mais o velho Camilo - acamaradados! Será que o velho Camilo sabia outras coisas? O que mal pensava, mal sentia. Porém, porém, ia passando além. A festa não existia. (ROSA, 2006, p. 227).

No final da vida, Manuelzão faz um balanço de tudo, conquistas de bens materiais, realizações pessoais, porém, suas preocupações superam a dimensão espacial concreta de suas conquistas materiais. É essencialmente relevante o modo de atuação dessa personagem e como ela desliza entre o plano do ser e do ter. Embora na primeira parte da novela o destaque seja dado ao desejo de Manuelzão de ter posses e ser proprietário da Samarra, ele vai caminhar, ao longo da narrativa, na direção de encontrar outros valores, no plano da experiência, das relações 
humanas, não somente no plano da posse de coisas materiais e da busca do status que isso dá.

$\mathrm{Na}$ literatura, de maneira geral, o espaço da percepção e a percepção do espaço ganham destaque devido a sua materialidade e densidade simbólica. Desse modo, o espaço é amplamente significado à medida que é percebido, apreendido pelas ações das personagens na interlocução com o meio físico. A relação corpo e espaço, dessa maneira, é vista como fluida, feita de movimentos e interfere na percepção dos objetos. Nesse sentido, o espaço como experiência do corpo remete à reversibilidade, interdependência dos sentidos, de modo que as sensações táteis se convertem em percepções visuais e vice-versa. No mundo percebido por Manuelzão, sensibilidade e reflexão são indissociáveis. Sujeito e mundo, corpo e espaço estabelecem um conjunto de relações que vão se ressignificando, de modo que, somente ao se perceber enraizado naquele espaço da natureza, tem uma visão profunda de sua existência, de sua condição no mundo:

Será que estava mesmo cansado nos internos, desnorteado com a festa? Porque, incertamente, dessa vez, ele dissaboria de ir, desgostava daquela boiada em jornadas, a ideia dela era pesada; e não aceitava um palpite ruim, o sussurro duns receios. Na saúde? As dormências, os arroxeados nos beiços, o retorto da canseira - e também, a qualquer esforço, com mais demora, logo lhe subia uma supitação. Ah essa falta-de-ar, o menos apetite de comer; umas dores... Suspeitava fosse via de morrer. A alma do corpo põe avisos. (ROSA, 2006, p. 175, grifos nossos).

Nessa passagem, Manuelzão aparece confuso. A reflexão da personagem sobre o envelhecer do corpo e as dores físicas levam-no a um "mergulho" em sua condição existencial. Durante toda a festa, ele se sente incomodado devido à sensação de que está envelhecendo, sente que o corpo está enfraquecido e que a morte se avizinha; está com um machucado no pé que lhe impõe algumas limitações. "E Manuelzão, [...] alçantes estandartes, de repente sentia a dor de uma ferroada no machucado do pé, esbarrava no instante, sem querer se abaixar nem soltar meio-gemido" (ROSA, 2006, p. 153). Manuelzão codifica a observação que faz sobre a festa mediado pelas impressões que tem de si mesmo. Há uma mudança significativa na maneira de o velho vaqueiro perceber o mundo, nas relações que modificam o modo de se portar, entre o início 
e o fim da festa. A insatisfação e a angústia influenciadas pela condição econômica e fragilidade física são gradualmente substituídas pela força do simbólico:

A festa? Sua era, dele, Manuelzão. Mas, de agora, por tudo, ele não queria mais mandar no governamento dela, sua razão. A lá era ele mordomo de festa?! Nenhum algum. Ora, mais, queria era apreciar aquilo, agora solto livre assim no meio, um, que nem não fosse o dono... O sono vinha dizendo. Uma ave-mariazinha por sua mãe, para a Santa do Socorro. Galo que até aqui não cantou, não conte mais com meu ouvido. Ô vida, bem dormida... De vagar. (ROSA, 2006, p. 186).

Durante boa parte da festa, Manuelzão mantém-se no controle, cuidando de tudo, não conseguindo se divertir como os convidados. A partir de certo momento, desejava participar da festa, afasta-se das preocupações materiais e deixa-se levar para o universo simbólico que o ambiente festivo propiciava. Há uma mudança nítida de perspectiva da personagem. "Manuelzão se sentara na roda dos hóspedes principais, o banquinho baixo encostado numa árvore, ele precisava, hoje não estava muito conseguido com o corpo. [...] Manuelzão preferia menos dizer. Ele sossegava por detrás do som das músicas" (ROSA, 2006, p. 223). A festa, como evento de simbolização da paisagem, reconfigura a relação de Manuelzão com a Samarra e com seus conflitos interiores.

Outra personagem que vive essa experiência com o espaço, marcada pela problematização interior e exterior conflituosa, é Soropita, na novela "Dão-lalalão - o devente". O espaço estruturador que delimita o percurso físico da viagem se entrelaça na construção da narrativa, que traz para o primeiro plano a vida passada da personagem. E é da interlocução entre a vivência, as marcas, as cicatrizes no corpo e as experiências trazidas pelas lembranças que se tem uma visão profunda de Soropita:

A palma-da-mão tocou na cicatriz do queixo; rápido, retirou-a. Detestava tatear aquilo, com seu desenho, a desforma: não podia acompanhar com os dedos o relevo duro, o encroo da pele, parecia parte de um bicho, se encoscorando, conha de olandim, corcha de árvore de mata. A bala o maltratara muito, rachara lasca do osso, Soropita esteve no hospital, em Januária. Até hoje o calo áspero doía, quando o tempo mudava. Repuxava. Mas 
doíam mais as da coxa: uma bala que passara por entre a carne e o couro, a outra que varara, pela reigada. [...]. Soropita levava a mão, sem querer, à orelha direita: tinha um buraco, na concha, bala a perfurara; ele deixava o cabelo crescer por cima, para a tapar dum jeito. Que não lhe perguntassem de onde e como tinha aquelas profundas marcas; era um martírio, o que as pessoas acham de especular. Não respondia. Só pensar no passado daquilo, já judiava. (ROSA, 2006, p. 476-477).

O passado é materializado no presente mediante a focalização das cicatrizes causadoras de desconforto. A dor física se mistura à dor de ter que lembrar o sofrimento, viver o conflito interior. É o próprio Soropita que toca o seu corpo trazendo à tona suas sensações e impressões. Como efeito, temos o desordenamento do seu mundo, que é trazido a lume: as inquietações, dúvidas e medos, sentimentos próprios de uma subjetividade fragmentada. Esses traços corroboram para as constantes oscilações entre o prazer e a dor, o medo e a coragem, buscando compreender o seu "estar-no-mundo". A construção de sentido tem como base a percepção tátil. Enquanto Soropita viaja, as dores do corpo físico e o cansaço, em função da longa distância percorrida a cavalo, misturam-se às tensões e conflitos internos. Ao controlar os pensamentos, tem as dores do corpo amortecidas. Por alguns momentos, consegue exaltar o prazer de viver:

O sobressonhar de Soropita se apurava, pesponto, com o avanço sem um tropeço naquele espaço calmo de estrada, Caboclim esquipando, reconhecendo o retorno. Vinham através de um malhador de pasto, a poeira vaporosa do esterco bovino chamava do sangue de Soropita um latejo melhor, um tempero de aconchego. Com o calor que o coxim da sela lhe passava para o fundo-das-costas - um calor grosso, brando, derramável, que subia às virilhas e se espalhava [...]. Também já trazia aquilo repetido na cabeça, o que mesmeava em todas as suas viagens. (ROSA, 2006, p. 484).

$\mathrm{Na}$ cena, destaca-se o entrelaçamento entre paisagem e personagem. Há uma identificação do bem estar físico e psicológico de Soropita e o estado de calmaria do ambiente externo. O espaço, nesse sentido, se junta à narração mediante a intervenção e experiência da personagem. $\mathrm{O}$ fato de Soropita conhecer o trajeto da viagem permite-lhe 
despreocupar-se, voltando-se para seus devaneios. Ao "sobressonhar" percorrendo o "espaço calmo da estrada", as sensações de dor e o cansaço do corpo da personagem são amenizados, permitindo-lhe deslocar-se divagando em seus pensamentos. Há, nessa composição do espaço, dois movimentos simultâneos: um para fora, as sensações do corpo e da paisagem; outro para dentro, estado de espírito. De acordo com Bento Prado Júnior, há nessa novela duas viagens intercaladas:

A princípio, ambas as viagens são descritas com o vocabulário do conforto e da felicidade; a paisagem exterior é interiorizada, percebida menos através da visão que separa a objetiva, do que através de uma cinestesia; $a$ paisagem interna é a rememoração da beleza de Doralda, antecipação de prazer de estar junto. [...] é o quase-sonho de Soropita, ruminação de si mesmo, que permite a ruminação da paisagem, que passa a latejar no corpopróprio. É esse sonho que dissolve o perfil nítido das coisas, dispersando-as em poeira vaporosa, em odor e gosto, fazendo a representação se diluir em pura afecção. O espaço se faz calmo e a percepção assume estilo erótico. (PRADO JÚNIOR., 1985, p. 202, grifos nossos).

Ao longo da novela, as transformações que ocorrem na paisagem correspondem à mudança interior de Soropita, percebidas por meio das sensações. A percepção intensa da natureza acompanha toda a narrativa e as viagens do protagonista. A paisagem é parte constitutiva do espaço no livro, que ganha outra dimensão, ao deflagrar a relação tensa da personagem, ao fazer a travessia real e a simbólica. Essa simbiose implica a análise da dinâmica interna da novela, provocando uma abertura para melhor compreensão do espaço e da narrativa.

Como se percebe, o mundo espacialmente estruturado em Corpo de baile tem relevância e é indicador de sentidos da própria lógica narrativa e manifesta vários tipos de realizações. Assim, dentro dessa dimensão corporal e sensorial da experiência receptiva, o espaço adquire profundo significado quando relacionado a sua "percepção tátil". O tato é um indicador de aproximação, portanto, um receptor que permite estimular várias sensações, sobretudo na relação com o outro e o mundo. Nas novelas, de modo geral, o "espaço tátil" tanto se expressa como categoria material como se processa em vias de deslocamento com 
propensa desmaterialização. ${ }^{1}$ Em "Dão-lalalão", como se vê, esse vetor espacial reforça a percepção sensível entre Doralda e Soropita. "Doralda repassava as mãos nas grossas costuras, numa por uma, ua mão fácil, surpresas de macia, passava a mão em todo o corpo, a gente se estremecia, de cócega não: de ser bom, de ânsia" (ROSA, 2006, p. 477). No trecho, o destaque dado à experiência sensorial, por meio das mãos de Doralda, é uma forma de salientar a comunicação afetiva entre as personagens. "Mel nas mãos, nem era possível se ter um mimo de dedos com tanto meigo" (ROSA, 2006, p. 477.) Nesse sentido, explora-se a categoria material, dando visibilidade à interação dos corpos.

Ao longo das sete novelas de Corpo e baile, a visibilidade do espaço, manifestada na relação personagem e natureza, se desdobra e se interpenetra em outras instâncias narrativas. Paisagem percebida e ato reflexivo das personagens se configuram num mesmo gesto. MerleauPonty considera que, na relação sujeito e objeto/espaço, há um modo particular de estruturação, não havendo o objeto, isoladamente, ou a paisagem em si, mas sujeitos e objetos se constituindo mutuamente. Esta dinâmica põe em jogo a matriz merlopontiana, de que corpo e espaço estabelecem, entre si, um conjunto de correspondências (MERLEAUPONTY, 2011, p. 193).

Em "A estória de Lélio e Lina", temos algo semelhante a essa situação de Soropita: a personagem Lina passa por uma experiência em que o corpo físico expressa um conjunto de "marcas" e sensações e significados do vivido. O envelhecimento do "corpo biológico" de Rosalina, sinais do tempo, pelo embranquecimento dos cabelos, pela fragilidade, é trazido à cena em contraponto à assimetria do corpo jovem de Lélio, e reflete um conjunto de representações e ambiguidades:

\begin{abstract}
Velhinha, os cabelos alvos. Mas, mesmo reparando, era uma velhice contravinda em gentil e singular - com um calor de dentro, a voz que pegava, o aceso rideiro dos olhos, o apanho do corpo, a vontade medida de movimentos - que a gente a queria imaginar quando moça, seu vivido. Velhinha como-uma-flor. O rastro de alguma beleza que ainda se podia vislumbrar. Como de entre as folhas de um livro-de-
\end{abstract}

\footnotetext{
${ }^{1}$ De acordo com Luis Brandão, "o espaço tátil pode tender a se desmaterializar, tornarse impalpável, preferencialmente só movimento” (BRANDÃO, 2013, p. 181).
} 
reza um amor-perfeito cai, e precisa de se pôr outra vez no mesmo lugar, sim sem perfume, sem veludo, desbotado, uma passa de flor. (ROSA, 2006, p. 307).

O corpo de Rosalina envelhecido sugere um conjunto de significações ligado à percepção. De uma maneira geral, há uma exploração das características físicas, expressão sensitiva dela, para se chegar a um aprofundamento subjetivo. Nessa descrição poética, a imagem da velhinha, oscilando entre presente e passado, luz e sombras, atrai o olhar para além da beleza física, focando em sua sabedoria. A imagem do corpo com a beleza desfocada coloca em evidência a subjetividade de Rosalina. A dimensão que a corporeidade assume nessa cena expressa uma associação da paisagem, simbolizada na flor sem perfume em que a velhice é problematizada, de modo que o corpo físico expande a comunicabilidade para além do mundo que o cerca.

Nas novelas analisadas, a paisagem é reveladora da subjetividade das personagens e intensifica a tensão narrativa. A paisagem não é uma simples exibição de cenas da natureza. Reflete a realidade vivida e a corporeidade da personagem no espaço. Assim, o corpo e a paisagem contêm em si a força integradora da materialidade do mundo das personagens.

Na novela “A estória de Lélio e Lina", uma análise de Jiní nos leva a uma reflexão relevante acerca da forma como o espaço é organizado no Pinhém e como esse modelo de representação influi no comportamento das personagens. A incorporação de Jiní neste espaço é problemática e reflete a condição dela de amante/prostituta. "[...] a Jiní não dava certeza de ser honesta" (ROSA, 2006, p. 274). Após se relacionar com vários homens, passar por vários donos, ter sido tratada como objeto sexual, ela é adquirida pelo dono da fazenda do Pinhém, que "propôs compra definitiva, fechou o negócio por bons contos-de-réis. Mandou até a Jiní em cidade, viagem tão longe, para tratar dos dentes" (ROSA, 2006, p. 274). Jiní ganha visibilidade na narrativa como um corpo disponível, que passa de mão em mão, como mercadoria. Ela se insere na rede "das mulheres faladas, como se diz no sertão mineiro, objetos de troca, de comércio, de lances", como observou Márcia Marques de Morais (2011, p. 202). Luiz Roncari destaca que Jiní passa de sujeito a "objeto de valor de uso". Nesse caso, o corpo de Jiní não é neutro, é um objeto altamente fetichizado: 
Desse modo, passando de mão em mão, sempre em movimento, ela conhece todas as metamorfoses do processo de circulação da mercadoria. Porém, como a mercadoria que não é uma coisa neutra, ela adquire também um poder em si, autônomo e ameaçador, que a transforma num fetiche; assim, os que encantam e se interessam por ela estão sujeitos a serem destruídos, na medida em que a relação que ela determina é entre objetos e não entre sujeitos: ou ela se dá pela troca simples entre objetos (ou corpos, para uso nas suas funções específicas) ou pela mediação do dinheiro, o equivalente geral; com isso ela nega ou subordina, aviltando-os, a razão e o espírito. (RONCARI, 2004, p. 184).

Jiní tem consciência do seu poder de sedução e da força do mundo do dinheiro, ao qual está subordinada. Essa personagem se vende também por posição social. A conduta dela mostra o seu desapego à vida matrimonial. Assim, não consegue manter por muito tempo a união com um único homem. Estabelece um jogo de envolvimento atendendo seus interesses próprios. Jiní é, na narrativa, o símbolo do erotismo que ganha visibilidade dentro da moral conservadora e do sistema familiar patriarcal do Pinhém, centralizado no poder masculino.

As personagens prostitutas de "A estória de Lélio e Lina", sobretudo Jiní, influem no comportamento e nos conflitos interiores de Lélio. A atração de Lélio por Jiní é imediata, mas tem um entrave, um obstáculo. Quando Lélio chega ao Pinhém, Jiní vive amasiada com Tomé Cássio. "[...] só estava vivendo com o Tomé de uns dois meses para cá, antes tinha morado com o Tiotino" (ROSA, 2006, p. 274). Na primeira vez que Lélio vê Jiní, sente-se atraído pelo corpo sensualizado dela:

A Jiní já estava na porta. A gente a ia vendo, e levava um choque. [...] Nem o Tomé não desapeava; só encomendou a ela qualquer coisa, Lélio não teve assento de entender o que. Ela entrava para ir buscar: desavançou num movimento, parecia que ia dançar em roda-a-roda. No lugar durava ainda aquela visão: o desliz do corpo, os seios pontudos, a cinturinha entrada estreita, os proibidos - as pernas... (ROSA, 2006, p. 277, 278, grifos nossos).

Com o corpo da Jiní em seu bailado, ao "dançar em roda-a-roda", instaura-se um movimento duplo do corpo erotizado, deslizando por 
debaixo da roupa. Na medida em que Lélio acompanha o deslocamento de Jiní, realçam-se as curvas de um corpo inacessível para ele. Jiní é esposa de Tomé, portanto, a princípio, proibida. No entanto, alguns dias depois, com a viagem de Tomé ao Mutum, Lélio, enfim, tem a oportunidade de ir até a casa de Jiní:

Foi. No lusco, a Jiní estava de branco, sentada na beira da laje; ficou em pé feito fogo. Nem ele pôde abrir nem ouvir palavra nenhuma, ela se abraçou, se agarrou com ele, era um corpo quente, cobrejante, e uma boca cheirosa, beiços que se mexiam mole molhados, que beijando. Ali mesmo, se conheceram em carne, souberam-se. E dali foram para a casa, apertados sempre, esbarrando a cada passo para o chupo de um beijo, e se pegando com as mãos, retremiam, respiravam com barulho, não conversavam.

Mal e nem conversavam, raras poucas vezes, as palavras curtas, na dura daqueles dias, quando cumpriam de se encontrar, dentro de casa, todas as noites sem uma só. Foram dias sem cabeça, Lélio se sendo em sonho no acordado, fevrém de febre. (ROSA, 2006 p. 326, grifos nossos).

O encontro se dá primeiro na parte externa da casa e se alarga para dentro dela. Temos aqui um jogo de sentido entre corpo/casa, o dentro e o fora. "O corpo quente" poroso, sexualizado, se coloca em evidência. A cena que se desloca para o interior da moradia ressignifica essa dupla representação, do corpo e da casa. "O encontro dos dois se assemelha ao da pulsão afetiva interna ou externa vinda da natureza" (RONCARI, 2004, p. 183). Após esse encontro às escondidas e do perigo de serem vistos, outros se sucederam. Lélio aproveita a ausência de Tomé Cássio para praticar sexo várias vezes com Jiní. No entanto, com o retorno do amigo da viagem que fizera ao Mutum, Lélio está impossibilitado de continuar a aventura e fica dividido entre o desejo de tê-la novamente e o remorso de trair o amigo:

E a ideia daquela volta do outro, certa sem remédio, ao fim de dias tantos e poucos, também fazia nele crescer os desesperos de desejo, infernava a gana. Afa, que queria o fundo do amar da mulatinha. Apertava-a com uns braços. Mal o mal, o pensamento de que, com pouco, com a vinda do Tomé, tudo se acabava, furtava-lhe qualquer hesitação, 
abafava todo começo pequeno de remorso. (ROSA, 2006, p. 327, 328).

Lélio sofre com os conflitos de consciência. O protagonista passa a viver atormentado, pois seu relacionamento com Jiní é gerador de vários problemas. Com a passagem de Lélio no Pinhém, oscilando entre o trabalho diário de vaqueiro e as noites com a amante, há um entrelaçar da realidade objetiva na realidade sensitiva que marca as múltiplas contradições dele ali. O espaço vai se desenhando a partir da experiência.

Desse modo, destaca-se a novela "Dão-lalalão" em que o corpo, paisagem e natureza adquirem vasta significação mediante a percepção do espaço. Por meio da impressão da natureza, cheiros e texturas captados da floresta, a personagem sente a paisagem, aflorando assim seus devaneios. Enquanto viaja, Soropita sente o aroma do capim evocando profunda sensibilidade:

Respirava. $\mathrm{O}$ aroma do capim apendoado penetrava no ar, vinha - nem se precisava de abrir os olhos, para saber das roxas extensões lindas na encosta - maduro o melosal. Chegar em casa, lavar o corpo, jantar. Da chegada, governando cada de-menor, ele ajuntava o reparo de tudo, quente na lembrança. O que ia tornar a ter. $O$ advoo branco das pombas mansas. (ROSA, 2006, p. 481, grifos nossos).

O estado de prazer da personagem torna-se indissociável da paisagem, e se prolonga da estrada para o ambiente da casa, formando uma unidade. Na primeira parte da citação, há um movimento que tem início com o enfoque na paisagem externa, que vai sendo percebida pela personagem através do "aroma do capim", e vai se intensificando até se misturar às sensações de bem estar dele, quando retorna para casa e para Doralda. No trecho em destaque, Soropita rememora como é chegar à casa depois de uma viagem. Ele relembra o prazer que terá ao tornar a ter Doralda, como um "advoo branco de pombas mansas". Nessa imagem, o pássaro, simbolicamente, está ligado ao sublime.

A metáfora da pomba mansa remete ao estado de paz e harmonia de Soropita ao ter em sua imaginação a certeza de que a amada estaria esperando por ele. Esse sentimento de encantamento do protagonista coloca a ex-prostituta em um grau de pureza. $\mathrm{O}$ contato com a paisagem e a alusão ao pássaro favorecem o aspecto sublime da cena. Assim, nesta 
perspectiva, a imagem do "advoo branco" remete ao estado de graça e serenidade e à atmosfera acolhedora propiciada pelo regresso tão desejado do viajante a casa.

A relação de reciprocidade entre personagem e espaço-paisagem assume contornos especiais em Corpo de baile. A estrada, que faz parte da composição da cena, não é apenas o cenário, funciona como referência do modo de ser do viajante. A vinculação entre o espaço percorrido e a personagem, a paisagem exterior e a interior, tem bastante destaque em "Dão-lalalão". Há uma estreita relação entre realidade objetiva e subjetiva, realidade e fantasia; desse modo, Soropita desloca-se duplamente tanto no espaço físico como no simbólico. Nesse entrelaçar, o espaço de tranquilidade da estrada, a passagem, harmoniza-se com o corpo da personagem, fundindo-se em uma única imagem.

A representação simbólica e imagética da casa é fato recorrente na produção dos sentidos no espaço. Na relação estabelecida entre o corpo, natureza e ambientação, as sensações perceptivas são intensas. Em meio a cheiros, aromas, configura-se uma imagem afetiva da casa que ganha amplitude e abrangência na imaginação da personagem:

Chegava a casa, abria a cancela, chegava à casa, desapeava do cavalo, chegava em casa. A felicidade é o cheio de um copo de se beber meio-por-meio; Doralda o esperava. Podia estar vestida de comum, ou como estivesse: era aquela onceira macieza nos movimentos, o rebrilho nos olhos acinte, o nariz que bulia - parecia que a roupa ia ficando de repente folgada, muito larga para ela, que ia sair de repente, risonha e escorregosa, nua, de de dentro daquela roupa. (ROSA, 2006, p. 483, 484).

Quando Soropita retorna à casa, reforça a percepção sensitiva, que dominava a paisagem externa, e agora é levada para o espaço de dentro da habitação. Destaca-se uma poeticidade no vínculo entre espaço físico e corpo, espaço imaginário e alma, "Doralda lá, esperando querendo seu marido chegar, apear e entrar, ao que era, um pássaro que ele tivesse, de voável desejo, sem estar engaiolado, pássaro de muitos brilhos, muitas cores" (ROSA, 2006, p. 484). O corpo de Doralda encena um movimento erótico. Ora é comparada a um pássaro, ora a uma égua. "Doralda, aquela elegância de beleza: como a égua madrinha, total aos guizos, à frente de todas - andar tão ensinado de bonito, faceiro, chega a mostrar os cascos..." (ROSA, 2006, p. 480). Há, nessa comparação com a égua, 
uma valorização da elegância de Doralda. Podemos dizer que a égua/ cavalo é, no mundo de vaqueiros, quase uma extensão do corpo, com forte valor positivo.

A relação paisagem/corpo/espaço também tem grande relevância na novela "Buriti", a partir da análise da personagem Maria Behú, que pode ser lida na perspectiva corpo/caixão. O espaço em que essa personagem ganha visibilidade é limitado e preenchido por uma atmosfera sombria, que se assemelha ao estado de tristeza dela. "Maria Behú gostava de rezar e de ser triste" (ROSA, 2006, p. 740). A personagem surge de forma misteriosa em um espaço oscilante e fragmentado. "Maria Behú murchara apenas antes de florir, não conseguira formar a beleza que lhe era destinada" (ROSA, 2006, p. 681). Maria Behú era filha de Iô Liodoro, e irmã de Maria da Glória, que era o seu oposto:

[...] Maria Behú era triste maligna por motivos de ser feia, e Maria da Glória ganhava essa alegria aprazível, por causa de tanta beleza? Ou era o contrário, então: que uma tinha crescido com todos os encantos, por já possuir a alma da alegria dentro de si; e a outra, guardando semente do triste e ruim, de em desde pequena, veio murchando e sendo por fora escura e seca, feito uma fruta ressolada? A essas coisas. Sorte. Quem souber o que é a sorte, sabe o que é Deus, sabe o que é tudo. Maria da Glória de certo em breve se casava, ia-se embora dali, do Buriti Bom, dava até pena a gente pensar nisso. Como que, ela se indo rapava a felicidade geral do lugar, de sua redondeza. A se assim, então, ela mesma ia ser sempre feliz? Dúvido-duvidável. A vida remexe muito. (ROSA, 2006 p. 642, 643, grifos nossos).

No contexto ficcional da novela "Buriti", Maria Behú tem uma vida recatada. A personagem dedica-se a rezar. Enquanto Maria da Glória e Lalinha são mulheres belas e cheias de vida, Maria Behú é descrita como tendo uma aparência feia, mas que se demonstra afável. "Maria Behú era uma estranha, sua doçura vinha de imensa distância. Maria Behú conheceria outros cansaços e consolos, e repouso, que a gente podia amenamente invejar, oh, às vezes" (ROSA, 2006, p. 794, 795, itálico do autor, negrito nosso). A passagem de Maria Behú pelo Buriti Bom é breve, e ela parecia não pertencer àquela paisagem, àquele lugar. "Para recomeçar, Maria Behú devia de ter pressa de morrer? Para recomeçar, 
ela rezava. Sua falta de beleza apartava-a das pessoas; assim como a beleza a todo instante se refaz, dos olhos dos que a contemplam" (ROSA, 2006, p. 690). O espaço habitado por Behú revela a transmutação dela num universo de santificação e finitude. Entre o adoecimento de Maria Behú e sua morte, há um breve intervalo de tempo, mas que marca um processo de mudança significativa na fazenda:

Fazia tempo que cessara a cerração de águas. O tempo era claro, balançava-se o vir do frio. A camélia plantada por mão de Lalinha deu flor. Honrou-se o aniversário de Behú, e o de iô Liodoro, festejaram-se tão simples como sempre, tomava-se vinho-do-porto e do de buriti, perfumoso vinho óleo. As primeiras boiadas engordadas se enviaram. Mataram, rio adiante, duas onças-pretas. Passou-se a Semana Santa.

E entanto Maria Behú adoecera, nas dores de um reumatismo tão forte, mandaram buscar médico, todos se reuniam no quarto de Behú, tanto carinho lhe davam; e ainda agora ela mal se levantava da cama, dia de sol, amparada em alguém e segurando uma bengala alta. Maria Behú não tinha uma queixa. (ROSA, 2006, p. 777).

Simbolicamente, Maria Behú morre, em um período de ressurreição e renovação, após a Semana Santa. O processo de transformação da personagem acompanha as mudanças no ciclo da natureza. "A camélia plantada por mão de Lalinha deu flor". De acordo com Ana Maria Machado, o nome de Maria Behú remete tanto ao universo fechado das convenções sociais quanto ao universo aberto do mundo vegetal. Simbolicamente, associa-se ao sentido de baú/buriti. "Behú-bu, bu de buriti. Behú beata. Behú baú. Behú de beleza e alegrias truncadas. Behú de som triste, lúgubre assustador" (MACHADO, 2003, p. 134, grifos da autora). Há uma simbologia entre o sentido de guardar os objetos no baú e manter o corpo intocado. A personagem era vista como santa:

- Bem dizia sempre o Chefe: que risadas, que corujas...

- Coitadinha, a lindeza dela!

- É santa. Não se cose mortalha?

- Ela vai vestidinha com vestido.

- É preciso ir recolher tudo o que é da roupinha dela, que está quarando no quintal, na corda... 
- Carece de não passar a ferro, e guardar, bem antes do enterro ter de sair...

- Uma morta santinha, assim, até me dá vaidades...

- Muitos morrem na lua-nova... (ROSA, 2006, p. 814).

O espaço em Buriti, configurado de forma tensa, é remodelado com a morte dessa personagem. "Cedo, na manhã, todos se uniram em exclamações e soluços. Maria Behú estava morta. [...] Maria Behú, sem perfil, os olhos fechados, nos lábios nem sofrimento nem sorriso, e a morte a embelezara. Partira, na aurora" (ROSA, 2006, p. 813). A morte reflete a inadaptação de Maria Behú à vida e reforça a ambiguidade dessa personagem:

Maria Behú se enterrou na Vila. Aquele dia inteiro, aos dobres, os sinos mais tristonhos. Os moradores, todos vinham visitar iô Liodoro e Glória, iô Ísio e Lalinha, na vassalagem do consolo - miúdo em prolongadas conversas - a fim de amansar a morte de Behú, segundo as regras antigas. [...] Tia Cló, à porta, alto chorou, quase num ritual; mas era também como se chorasse de uma alegria, de rever outra vez reunidos ali os outros, os que a morte não levara. (ROSA, 2006, p. 815).

Fica evidente que a presença dela ali naquela fazenda é marcada por solidão e melancolia, que se acentuam até dissolver-se com a concretização da morte da personagem. Através da leitura do espaço, pode-se dizer que as personagens no Buriti Bom compõem um universo de conflito que se reorganiza continuamente. $\mathrm{O}$ espaço/paisagem é um influenciador da atmosfera de tristeza. Maria Behú performatiza um corpo entre fronteiras, inadaptável ao "Buriti", que não se define nem como totalmente bom, nem como mau. Certamente, reforça a simbologia do equilíbrio precário que desestabiliza as personagens que habitam o Buriti Bom.

O espaço experiencial, em Corpo de baile, aparece também ligado à percepção gustativa, que tem a função de trazer à cena a culinária do sertão, intercalada em alguns acontecimentos importantes, como as festas, comemorações, estreitamento das relações afetivas em que se celebram os encontros. Ao longo do livro, muitos trechos se destacam, trazendo à luz as relações perceptivas das personagens. As referências à percepção gustativa têm desdobramentos distintos na obra. Um efeito de sentido 
que esse elemento proporciona à narrativa está ligado principalmente à cultura e a hábitos alimentares sertanejos típicos:

O almoço era farto, se comia pai-com-filho: angu de fubá e papas de fubá com carne de osso guisada; e cansanção - aquela urtiga verde-pato, verde brilhante, que ardia e servia também para se esfregar em peito de galo-capão, para que por precisão de nele se coçar ele aprendesse a agasalhar e criar os pintos, chocados por galinha (ROSA, 2006, p. 310).

Como faz parte da estratégia discursiva de Corpo de baile, as inserções desses elementos não são gratuitas e estão carregadas de simbolismo. Os aportes sensoriais fazem parte da elaboração formal do texto e refletem em seus efeitos. Na cena, o narrador vale-se de percepções espaciais pelo paladar para compor o ambiente do almoço, que aparece repleto de condicionamentos culturais. A percepção da vida sertaneja pelo paladar tem grande destaque na festa de Manuelzão, como se descreve na cena:

No terreiro, os músicos paravam comendo. Todo o mundo comia, na porta da cozinha, no quintal, em toda a parte. Graças a Deus. Aquela quantidade de latas vazias, sempre guardadas - latas que tinham sido de marmelada, de goiabada, de tudo - prestavam agora sua serventia. Mas muitos, pobres, traziam pendurada na cintura sua cuia de receber. As grandes panelas de barro preto cozinhavam gordo, sem esbarrar. Pessoa, por mais desconhecida que fosse, não deixava de ganhar seus dois pedaços de galinha e um montezinho de arroz; a farinha estava pública. Toda água que o Chico Carreiro carreasse das Pedras, mais fria ou mais quente logo se bebia. (ROSA, 2006, p. 207).

A culinária sertaneja é reveladora dos hábitos e costumes e possibilita, nesse momento da festa, em que todos param para se alimentar, uma intensificação dos laços comunitários e de compartilhamento. Os utensílios, a cuia, a panela de barro preto, as latas reaproveitadas são elementos que constituem a cena e estão ligados aos hábitos e costumes sertanejos. A comida servida na festa é simples: arroz branco, galinha e a farinha, mas suficientes para satisfazer os convidados. De acordo com Sabrina Sedlmayer, o tratamento dado ao tema da comida na 
literatura é um campo investigativo bastante potente, que permite "integrar e relacionar reflexões críticas acerca da memória, do espaço, da experiência, do corpo e das relações entre a tradição e a modernidade" (SEDLMAYER, 2014, p. 141). A culinária sertaneja é uma espécie de linguagem do sertão e ganha espaço de diferentes formas enfatizando costumes regionais. Dessa maneira, o destaque dado à faculdade gustativa funciona, no livro, como uma "janela aberta" para o interior do sertão. Na obra rosiana, destaca-se a preparação de alimentos, sobretudo doces, com as frutas do cerrado. A preparação de doces é um costume tradicional no sertão. Na novela "A estória de Lélio e Lina" há uma cena, bastante representativa, que focaliza dona Rosalina preparando doce de mangaba. É um momento de intenso valor simbólico que singulariza o cotidiano da velhinha:

Assim mesmo, no domingo não deixou de passar em casa de dona Rosalina. Foi, e não sabia esconder que estava apressurado, escravo em si das horas, não se consentia inteiro de pouso. A velhinha estava fazendo doce de mangabas: - "Você vai provar, depois. O doce melhor que tem neste mundo..." As mangabas de-vez, muitas mãos, muitos dias, ferventadas, no tacho de cobre. Com espinhos de laranjeira e palitos de taquara, ela continuava a crivar, uma a uma, devagarinho, para as livrar do visgo borrachento. (ROSA, 2006, p. 328, grifos nossos).

O doce que está sendo feito constitui um apelo irresistível para Lélio, que chega ao local bastante aborrecido. A interação dele no ambiente vai sendo estabelecida gradualmente. O ritual da preparação do doce dialoga com o ritual de Lélio no Pinhém. Ali, o rapaz está se relacionando com várias mulheres sem conseguir viver com nenhuma delas o amor que tanto procura. Por meio da percepção sensorial, o espaço é transformado. O rapaz é acolhido e encontra a paz que procura. Lina nutre Lélio de doce e de palavras de afeto. Enquanto prepara o doce, a velhinha conversa, simbolizando o duplo sentido de alimentar e compartilhar sabores e segredos. As sensações gustativas intensificadas ajudam na aproximação das personagens. Nas recordações do encontro que teve com a mocinha de Paracatu, a percepção gustativa foi um dos pontos de referência da aproximação dele a ela. Uma das formas usadas por Lélio para seduzir Sinhá-Linda, a mocinha da cidade, foi oferecer a ela uma referência da culinária sertaneja, o doce de buriti: 
Como viu que ela desejava sempre provar das comidas e bebidas sertanejas - achara choco o chá de congonha, mas apreciara muito o de cagaiteira, que é dourado lindo e delicado e tem os suaves perfumes. [...] Acordou antes do dia, montou e galopou meia-légua, até onde estavam dizendo que se conseguia achar um doce de buriti, bom especial. Comprou, mesmo com a tigela grande - não queriam vender aquela tigela, bonita, pintada com avoejos verdes e roxas flores. Trouxe, deu a ela, receoso, labasco, sem nenhuma palavra podida. Ela riu, provou, e sacudiu a cabecinha: disse aos rapazes que era um doce grosseiro, ruim. (ROSA, 2006, p. 259, grifos nossos).

$\mathrm{Na}$ cena, os aspectos sensoriais relacionados ao paladar evocam uma tensão entre Lélio e Sinhá-Linda. O doce de buriti, usado aqui como pretexto de Lélio para conquistar a mocinha da cidade, não tem o efeito esperado, conforme expectativa do rapaz. Essa quebra de sentido se constrói em confluência com as interações afetivas. A abordagem malsucedida gera ambiguidade e faz que o doce se torne ruim. O paladar, gradiente sensorial ligado à percepção gustativa, é "responsável pelas sensações de doce e amargo e todas as nuances que se situam entre esses dois polos" (BORGES FILHO, 2009, p. 182). Assim, em todo o livro, esses pequenos episódios, que surgem entrelaçados à dimensão da paisagem e do espaço em deslocamento, ajudam a traçar um painel representativo das tensões e ambiguidades das personagens. O sertão, como espaço da memória associado aos sentidos gustativos, cria paisagens poéticas que vão desenhando em meio aos percursos das personagens. Segundo Borges Filho, "há duas maneiras de o paladar entrar na percepção do espaço: pelo maravilhoso ou pela conotação" (BORGES FILHO, 2009, p. 183). No caso, ambas as formas são exploradas nas novelas.

Outro sentido relacionado ao buriti, que aparece em diversos momentos em Corpo de baile, está no resgate da memória cultural da culinária do sertão. Os cheiros e os sabores são ingredientes narrativos indispensáveis. Nesta perspectiva, o livro nos permite pensar o espaço na sua relação com a paisagem sertaneja, por meio da tematização das sensações despertadas pelos sentidos. Na novela "Buriti", há uma cena emblemática, que faz referência ao vinho extraído da palmeira do sertão: 
O vinho-doce, espesso, no cálice, o licor-de-buriti, que fala os segredos dos Gerais, a rolar altos ventos, secos ares, a vereda viva. Bebiam-no Lala e Glória. - "Vigem, que isto é forte, pelo muito unto - para se tomar, a gente carece de ter bom fígado..." - nhô Gal poetara, todos riram. Ria-se; e era bom. Bebia-o Lala, todos riam sua alegria, era a vida. Por causa dela, iô Liodoro mandara servir o vinho, era um preito. (ROSA, 2006, p. 797, 798, grifos nossos).

É importante ressaltar o destaque dado aqui ao "licor-de-buriti, que fala os segredos dos Gerais". A bebida está no centro da cena em torno da qual se compõe o foco do encontro. O buriti é um símbolo forte em Corpo de baile, que se vincula à dimensão ambígua das personagens. Desse modo, a palmeira que surge integrada ao espaço sertanejo atua como âncora do sertão. Nessa ordem, o vinho do buriti é um ativador dos segredos das personagens. O licor de buriti faz parte da culinária sertaneja, intensificado nesse ambiente de trocas simbólicas ligadas ao paladar. Ainda na novela "Buriti", as cozinheiras constituem um corpo só, que traduz um saber e um fazer:

E as mulheres da cozinha, que eram moças e velhas, risadinhas tossicavam e conversavam irmãs as novidades repassadas, como os acontecimentos da vida chegavam a elas já feitos num livro de figuras, ali entre resinas e fumaças, as mulheres-da-cozinha leve se diziam:

- Ele devia de tomar chá de erva-do-diabo...

- Sei assim, de um parente meu que ensandeceu: quem fica pobrezinho de não dormir, acaba é com sofrer de amores... -É?! Morde aqui... Prega na parede...

[...]

Elas torravam café, o ar ardia naquele cheiro entrante, crespo, quente e alargado. Elas eram muitas, sempre juntas, falavam sempre juntas, as Mulheres da Cozinha. (ROSA, 2006, p. 778, 779, grifos nossos).

$\mathrm{Na}$ cena, o cheiro do café sendo torrado, que exalava daquela cozinha, está ligado à imagem das mulheres ali ativas. $\mathrm{O}$ processo de elaboração narrativo destaca essas mulheres dentro de uma rede simbólica de ocultamento e revelação. A construção do espaço da cozinha tem dupla função: é um lugar de cozinhar e conversar. Reflete uma significação de poder e manipulação, e converte-se num importante índice de significação 
da novela. Na configuração da paisagem sertaneja que envolve essas mulheres encontram-se marcas das tradições, superstições, crendices e costumes populares. A marca distintiva das cozinheiras é o exercício desse papel de mediação do discurso revelador das crendices do sertão, e também sobre o que se passa na vida das pessoas ali. " $E$ as mulheres falavam, e a cozinha emitia sempre seu espesso cheiro - de fumado e resinas, de lavagens e farelos. Ali era uma clareira" (ROSA, 2006, p. 722, grifos nossos).

Como se vê, a paisagem literária em Corpo de baile é peça chave na reinvenção do mundo do sertão e funciona como um recurso de instauração do ficcional na narrativa. É um dos elementos potencialmente integrados ao processo de representação do espaço e das interações culturais, sociais e estéticas do texto. A percepção sensorial da paisagem pelas personagens constitui um conjunto significante da organização do espaço no livro. No universo perceptivo das novelas, o espaço/ paisagem constitui um prolongamento do próprio corpo das personagens em cena. Nessa configuração da experiência do corpo, a percepção relaciona-se tanto ao mundo das interações sociais quanto aos aspectos da subjetividade, das tensões, paradoxos e experiências afetivas.

Em Corpo de baile, a noção de espaço é apreendida por meio da experiência perceptível. Assim, a paisagem sinaliza peculiaridades que não permitem percebê-la como um fundo em que se depositam as personagens, mas como a expressão da vivência interior delas. A relação corpo-paisagem é transfigurada na dimensão do espaço e levada no livro em suas variadas perspectivas, como demonstra-se aqui. $\mathrm{O}$ espaço, nas novelas, tem como fundamento a exploração sensorial, privilegiando a relação de interdependência entre as personagens e o mundo.

\section{Referências}

BORGES FILHO, Ozíris. Espaço, percepção e literatura. In: BORGES FILHO, Ozíris; BARBOSA, Sidney (org.). Poéticas do espaço literário. São Carlos: Claraluz, 2009. p. 167-189.

BRANDÃO, Luis Alberto. Teorias do espaço literário. São Paulo: Perspectiva, 2013.

COLLOT, Michel. Poética e filosofia da paisagem. Organização da tradução de Ida Alves. Rio de Janeiro: Oficina Raquel, 2013. 
HOUAISS, Antônio. Dicionário Houaiss da Língua Portuguesa. Rio de Janeiro: Editora Objetiva, 2001.

MACHADO, Ana Maria. Recado do nome: leitura de Guimarães Rosa à luz do nome de seus personagens. 3. ed. Rio de Janeiro: Nova Fronteira, 2003.

MERLEAU-PONTY, M. Fenomenologia da percepção. 4. ed. Tradução de Carlos Alberto Ribeiro de Moura. São Paulo: Martins Fontes, 2011.

MORAIS, Márcia Marques. Mulheres. A magmática pulsação da escrita. In: PASSOS, Cleusa Rios P.; ROSENBAUM, Yudith (org.). Escritas do desejo: crítica literária e psicanálise. São Paulo: Ateliê Editorial, 2011. p. 201-216.

PRADO JÚNIOR, Bento. O destino decifrado: Linguagem e existência em Guimarães Rosa. In: . Alguns ensaios: filosofia, literatura, psicanálise. São Paulo: Max Limonad, 1985. p. 195-226.

RONCARI, Luiz. O Brasil de Rosa: mito e história no universo rosiano: o amor e o poder. São Paulo: Editora UNESP, 2004. DOI: https://doi. org/10.7476/9788539302819.

ROSA, João Guimarães. Corpo de baile. Rio de Janeiro: Nova Fronteira, 2006. Edição Comemorativa.

SEDLMAYER, Sabrina. Comer o passado como pão de fome: relações entre comida e literatura. Abril: Revista do Núcleo de Estudos de Literatura Portuguesa e Africana da UFF, Niterói, v. 6, n. 12, p. 141-152, abr. 2014.

Recebido em: 14 de janeiro de 2020.

Aprovado em: 3 de março de 2020. 